\title{
INTEGRATION OF BUILDING INFORMATION MODELING (BIM) AND LEED FOR A GREEN BUILDING RATING
}

\author{
Mizanoor Rahman ${ }^{*}$, Sohana Alam Mim² and Shamanta Azad Oshin ${ }^{2}$ \\ ${ }^{1}$ Assistant Professor, ${ }^{2}$ Student \\ Department of Building Engineering and Construction Management (BECM), Khulna University of \\ Engineering and Technology, Khulna-9203, Bangladesh
}

Received: 11 October 2020

Accepted: 17 March 2021

\begin{abstract}
Green building design and construction is a global demand to save this earth. Leadership in Energy and Environmental Design (LEED) is the world's most widely implemented sustainable building rating system. Building Information Modeling (BIM) technology assist to keep multi-disciplinary information into a single model, and it provides an ability to perform this research. The aim is to assess the pre-certification of a proposed residential building project in integration with BIM and LEED and find out the impact of cost for a green building project. A Prototype 3D model was developed by BIM technology for the LEED certification process. A total of 704 simulations was conducted by using Green Building Studio (GBS) tools. All simulation results were calculated based on nine categories of the LEED rating system. The results of this study indicate that the lifecycle cost can be reduced significantly for a high-performance green building despite of having a high initial investment cost.
\end{abstract}

Keywords: BIM, Costing, LEED, Performance, Rating, Simulation

\section{INTRODUCTION}

LEED is a globally recognized green building certification scheme that provides third parties with documentation of the creation and maintenance of buildings and cities using techniques to increase efficiency throughout all the key sections of the project. According to LEED, the green building rating system is divided into 8 types. However, for new construction, the Building Design and Construction $(\mathrm{BD}+\mathrm{C})$ is usually followed. The rating system is categorized into nine basic areas: Integrative process, Location and transportation, Sustainable Sites, Water Efficiency, Energy and Atmosphere, Materials and Resources, Indoor Environmental Quality and Innovation and Regional priority. Every category has different credit points. In this study, different types of passive technologies have been incorporated in the building model to earn LEED $(\mathrm{BD}+\mathrm{C})$ credits points. Depending on the earned LEED $(\mathrm{BD}+\mathrm{C})$ points, out of a total of 110 points, a building can be classified as LEED Certified, LEED Silver, LEED Gold and LEED Platinum (Azhar et al., 2011).

Table 1 shows the threshold of the allowable points according to LEED $(\mathrm{BD}+\mathrm{C})$ rating system where minimum 40 points are needed in order to be LEED $(B D+C)$ certified and minimum 80 points are needed for the highest level of green building rating.

Table 1: Range of LEED Point for Certification

\begin{tabular}{cc}
\hline Certification Level & Required Score \\
\hline LEED Certified & $40-49$ \\
LEED Silver & $50-59$ \\
LEED Gold & $60-79$ \\
LEED Platinum & $80-110$ \\
\hline
\end{tabular}

BIM is a 3D model based technology where all the properties of the objects are incorporated into the model. There are many BIM tools available in the AEC industry. However, in this research, three BIM tools have been used for building energy performance and renewable energy potential of a residential building which are given below:

I. $\quad$ Autodesk Revit ${ }^{\circledR}$ version 2019

II. Autodesk Green Building Studio and

III. Autodesk Insight 360

Autodesk Revit is a BIM tool for architects, landscape architects, structural engineers, mechanical, electrical, and plumbing (MEP) engineers, designers and contractors. A modular cloud-based service, Autodesk Green Building Studio enables the designer to run building output simulations to minimize energy usage and maximize function 
earlier on in architecture for carbon-neutrality. In addition, the Autodesk Insight 360 is an important and coherent roadmap to optimize building efficiency and environmental efficiency.

Moreover, green architecture has become the ethical 'in' in a society that is exhausting our natural capital and trying to rescue our planet from desperation. This can be achieved however only through a concerted effort by architects, engineers and construction enterprises, and of course through the support of the citizen concerned (Bolman and Deal, 2011). Green Building gives our community the most significant value. It has significant impacts on our atmosphere and our biodiversity by a decrease in the use of water and energy sources polluting our environment including coal and carbon dioxide (Council, 1996; Zach et al., 2013). Green construction not only cuts water pollution, but also conserves natural resources and encourages sustainability and increases our quality of air and water. Green construction also decreases the carbon emissions by reducing the amount of garbage and toxic gasses being emitted into the environment (Council, 1996). Figure 1 represents the basic elements of a typical green building project.

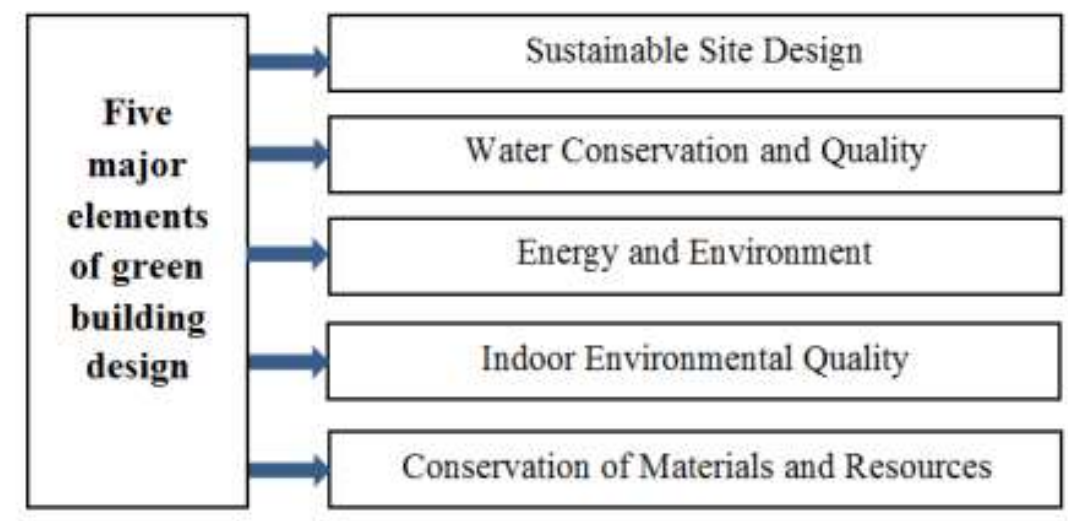

Figure 1: Elements of a Green Building Project (Ragheb et al., 2016).

To enhance the building performance different passive technologies are incorporated in the residential model. Passive house technologies and low energy buildings include several concepts like daylighting, highly efficient HVAC equipment, natural ventilation, energy efficiency, water efficiency etc. Among the LEED (BD+C) nine main categories, the integrative process, location and transportation, sustainable sites, materials and resources are constant for a particular location(Wu and Issa, 2010) and these four categories have been considered as constant credits for all cases in this study. The other categories such as water efficiency, energy and atmosphere, indoor environmental quality are variable through which the model can gain credits with the incorporation of passive house technologies. The categories innovation and regional priority are not considered in this study because the model has not been accepted yet by the USGBC council (Azhar, 2010). So, in this study, the variable categories are analyzed through Green Building Studio (GBS) (Azhar et al., 2011). The process can be summarized with the following four steps:

Step 1: incorporate all passive technologies into the energy model

Step 2: run energy simulation and evaluate the best passive technology

Step 3: provide renewable energy to the building footprint

Step 4: develop the highest certified model by LEED $(B D+C)$

Previous researches (Jalaei and Jrade, 2015; Azhar et al., 2011) were limited to Energy and Atmosphere (EA) and Materials and Resources (MR) categories only and cost estimation was not conducted at all. In the architectural, architecture and construction (AEC) sector, the convergence of building information modeling (BIM) and green building design and construction were addressed for some time. The Architecture, Engineering, Construction and Service (AECO) industry in parallel with a constant push of green building movement over the last two decades has experienced secure growth by BIM implementation. While both definitions are different, BIM and green building together can resolve the problems confronting the AECS industry in terms of sustainability and longevity. This reduces the rate of climate change and makes a positive contribution to the conservation of our environment (Council, 1996)Thus, the aim of this study is to carry out a holistic analysis along with cost estimation as well. A demo residential building has been considered to assess LEED $(\mathrm{BD}+\mathrm{C})$ certification by using BIM technology. The renewable system, daylighting, will also be incorporated and analyzed in this research to certify the building according to USGBC guideline (Council, 1998). BIM is aiding with evaluating building energy efficiency. 


\section{METHODOLOGY}

This study has been conducted by following the procedure that is shown in Figure 2 where LEED (BD+C) point is assessed for each of the design alternatives along with cost estimation. Various contributing factors have been modified and re-assessed the building for improving building performance in terms of LEED (BD+C) rating with cost estimation for each alternative design case.

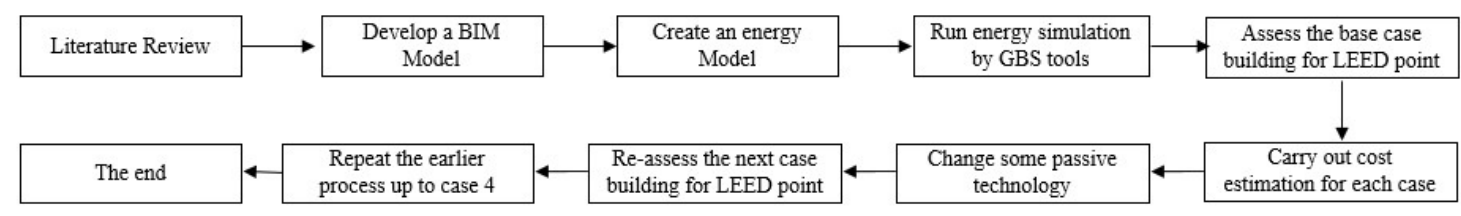

Figure 2: Concept mapping of the study.

\subsection{Develop a BIM Model by Autodesk Revit}

Autodesk Revit ${ }^{\circledR}$ is a recent invention of BIM technology which is very intelligent and parametric. The model has been created by Autodesk Revit ${ }^{\circledR}$. Figures 3 and 4 show the residential building which has been created as a single unit five-storied building. It has three bedrooms, one living room and one dining room and the other requirements. The total floor area of five stories is $14900 \mathrm{sft}$ with four balconies. The location of the building is in Khulna city of Bangladesh. This model of the Case Building is a parametric energy model which means each element is linked with other elements.

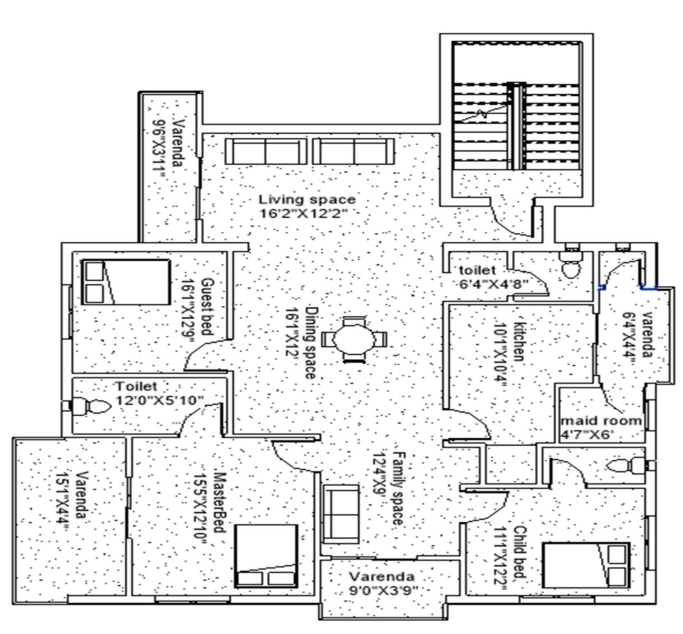

Figure 3: Typical Floor Plan of the Case Building.

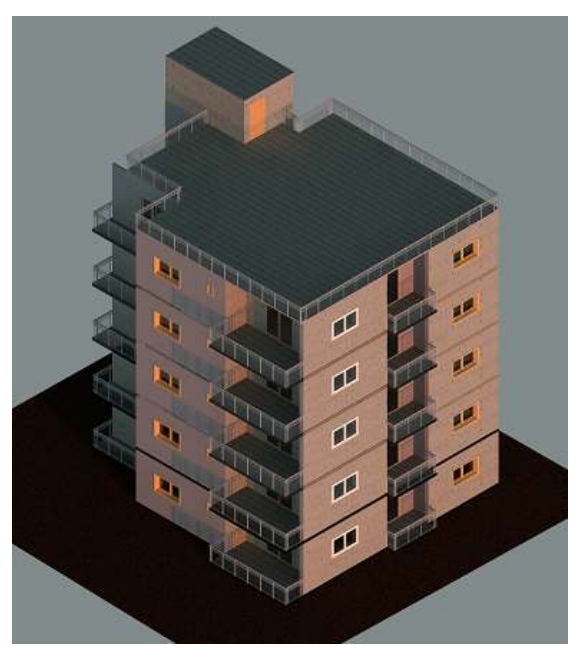

Figure 4: 3D View of the Case Building.

\subsection{Setting Different Parameters of the Building}

Building consumes $40 \%$ of the total energy consumptions (Benmansour et al., 2014). A major portion of the energy is consumed by the residential building sector. For this reason, a multi-story residential building has been chosen as a case study. Energy performance has been evaluated at the pre-construction stage for LEED $(B D+C)$ rating certification. Different parameters such as Location, Mode, building type, building operating system, HVAC systems etc. (Cidell, 2009) have been set as parameters during energy simulation. After setting all energy options, an analytical model has been created. Autodesk Revit ${ }^{\circledR}$ generates a gbXml file and after that it is transferred to Green Building Studio (GBS) environment. Finally GBS reads the gbXml file and runs the simulation and provides results.

Window to wall ratio is another influencing factor that affects the energy performance of a building. It represents how much window opening has prevailed in any wall area. It is very important for daylight, solar heat gain and natural ventilation. It also includes shading of the window. So, by implementing the window shading and window wall ratio property, it can make the best use of daylight, natural ventilation and optimize heat gain from outside which is incorporated in this study. In addition, consumption of water also impacts building energy performance. 
Green product is considered to reduce the normal uses of water in the residential building. Material properties of windows are also important for the reduction of energy consumption (Boukhattem et al., 2017; Benmansour et al., 2014). Sustainable windows properties have also been considered to reduce the energy consumption.

\subsection{Create Analytical Energy Model}

In order to run energy simulation, an analytical energy model (Figure 5) is created where the influencing factor is passive technologies, such as, roof insulation, building orientation, window wall ratio, natural ventilation, water use reduction, water usage for irrigation \& window properties.

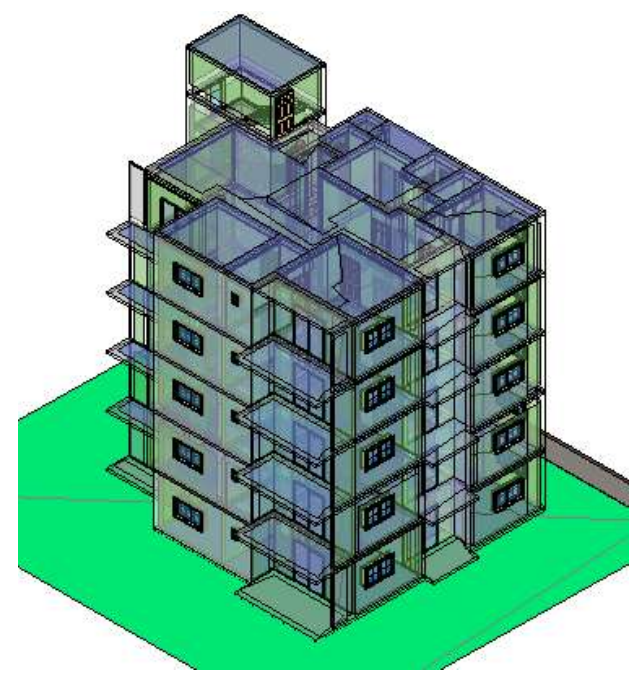

Figure 5: Analytical Energy Model of the Case Building.

The case building project is located at Khulna which is the South-Western region of Bangladesh and the climate of Khulna is mixed of wet and warm. In this area, therefore, solar heat gain is very prevalent. For reducing heat gains, wall isolation is important. Since it is a building with many stories, heating benefit from the roof is less than a wrap (Bolman and Deal, 2011). Heat gain causes at the five floors only. For this reason we considered only some roof combinations. Sun rays work at various directions on the structure. Sunlight intensity also depends on the sun angle and building orientation (Schmalensee et al., 1998). The sun angle and building orientations have been properly correlated to reduce a significant amount of heat gain.

\subsection{Create Various Combinations of Passive Technologies}

The building orientation has been changed during each of the simulations and the angle of rotation has been represented in Table 2, where the building is rotated clockwise up to 315 degree from the base case.

Table 2: Different Types of Building Orientation

\begin{tabular}{cc}
\hline Rotation ID & Magnitude of Rotation(clock wise) \\
\hline R1 & $0^{\circ}$ (base case) \\
R2 & $45^{\circ}$ \\
R3 & $90^{\circ}$ \\
R4 & $135^{\circ}$ \\
R5 & $180^{\circ}$ \\
R6 & $225^{\circ}$ \\
R7 & $270^{\circ}$ \\
R8 & $315^{\circ}$ \\
\hline
\end{tabular}

Five types of wall as a passive technologies have been considered in this study. From Table 3 it is found that for 10 " wall the composition is 4 "brick + 4"rubber + 2"aluminium and for 5"wall the composition is 2.5 " brick + 2 " rubber +0.5 " aluminum for base case. 
Table 3: Different types of building envelops

\begin{tabular}{|c|c|c|}
\hline Wall Type & Specifications of Wall Materials & Schematic Illustration \\
\hline Base Wall & $\begin{array}{l}4 " \text { brick wall }+4 " \text { rubber }+2 " \text { aluminium and } 2.5 " \\
\text { brick wall }+2 \text { " rubber }+0.5 \text { " aluminium }\end{array}$ & \\
\hline Wall 1 & $\begin{array}{l}4 \text { " brick wall }+4 \text { " wood wool }+2 \text { " rubber and } 2.5 \text { " } \\
\text { brick wall }+2 \text { " wood wool }+0.5 \text { " rubber }\end{array}$ & \\
\hline Wall 2 & $\begin{array}{l}4 \text { " brick wall }+4 \text { " polystyrene }+2 \text { " hardwood and } \\
2.5 \text { " brick wall }+2 \text { " polystyrene }+0.5 \text { " hardwood }\end{array}$ & \\
\hline Wall 3 & $\begin{array}{l}\text { 4" brick wall }+4 \text { " plywood }+2 \text { " cork and } 2.5 \text { " brick } \\
\text { wall }+2 \text { " plywood }+0.5 \text { " cork }\end{array}$ & \\
\hline Wall 4 & $\begin{array}{c}5 \text { " lightweight concrete }+3 \text { " fibreglass }+2 \text { " plastic } \\
\text { board and } 2.5 \text { " lightweight concrete }+1.5 \text { " } \\
\text { fibreglass }+1 \text { " plastic board }\end{array}$ & \\
\hline Wall 5 & $\begin{array}{l}5 \text { " brick wall }+4 \text { " glass fiber }+1 \text { " aluminium and } \\
2.5 \text { " brick wall }+2 \text { " glass fibre }+0.5 \text { " aluminium }\end{array}$ & \\
\hline
\end{tabular}

There is a significant impact of roofing materials, window to wall ratio, and window material on energy consumption. Hence, roofing material, window to wall ratio and window materials have also been changed in every simulation. The configuration of the roofing materials, types of window materials and window to wall ratio are shown in Table 4, Table 5 \& Table 6 respectively.

Table 4: Different types of roof materials

\begin{tabular}{lcll}
\hline Roof ID & Specifications of Roofing Materials & Schematic Illustration \\
\hline Base roof & 4 " lightweight concrete+ 2" expanded polystyrene & \\
\hline Roof 1 & 4 " lightweight concrete+ 2" rubber & \\
\hline Roof 2 & 4 " lightweight concrete+ 2" mineral wool & \\
\hline Roof 4 & 4 " lightweight concrete+ 2" rock wool & \\
\hline
\end{tabular}


Table 5: Properties of Different Window Materials

\begin{tabular}{cc}
\hline Window ID & Specifications of Windows \\
\hline window 1 & Double glazing $-0.25 "$ thick - clear/low-E $(\mathrm{e}=0.05)$ glass \\
window 2 & Double glazing -0.25 " thick - clear/low-E $(\mathrm{e}=0.1)$ glass \\
window 3 & Double glazing $-0.25 "$ thick - clear/low-E $(\mathrm{e}=0.2)$ glass \\
window 4 & Double glazing $-0.25 "$ thick - blue green/low-E $(\mathrm{e}=0.05)$ glass \\
window 5 & Double glazing $-0.25 "$ thick - clear/low-E $(\mathrm{e}=0.05)$ glass \\
\hline
\end{tabular}

Table 6: Variation of Window to Wall Ratio (WWR)

\begin{tabular}{|c|c|}
\hline Types of WWR & Configuration of WWR \\
\hline WWR 1-N & $\begin{array}{c}\text { Northern Walls_95\% -- Window Shades - North_2/3 Win Height -- Window Glass Types } \\
\text { - North_Trp L }\end{array}$ \\
\hline WWR 2-N & $\begin{array}{c}\text { Northern Walls_65\% -- Window Shades - North_2/3 Win Height -- Window Glass Types } \\
\text { - North Trp L }\end{array}$ \\
\hline WWR 3-N & $\begin{array}{c}\text { Northern Walls_30\% -- Window Shades - North_2/3 Win Height -- Window Glass Types } \\
\text { - North_Trp L }\end{array}$ \\
\hline WWR 1-S & $\begin{array}{c}\text { Southern Walls_95\% -- Window Shades - South_2/3 Win Height -- Window Glass Types } \\
\text { - South_Trp L }\end{array}$ \\
\hline WWR 2-S & $\begin{array}{c}\text { Southern Walls_65\% -- Window Shades - South_2/3 Win Height -- Window Glass Types } \\
\text { - South Trp L }\end{array}$ \\
\hline WWR 3-S & $\begin{array}{c}\text { Southern Walls_30\% -- Window Shades - South_2/3 Win Height -- Window Glass Types } \\
\text { - South_Trp L }\end{array}$ \\
\hline WWR 1-W & $\begin{array}{c}\text { Western Walls_95\% -- Window Shades - West_2/3 Win Height -- Window Glass Types - } \\
\text { West_Trp LoE }\end{array}$ \\
\hline WWR 2-W & $\begin{array}{c}\text { Western Walls_65\% -- Window Shades - West_2/3 Win Height -- Window Glass Types - } \\
\text { West_Trp LoE }\end{array}$ \\
\hline WWR 3-W & $\begin{array}{c}\text { Western Walls_30\% -- Window Shades - West_2/3 Win Height -- Window Glass Types - } \\
\text { West_Trp LoE }\end{array}$ \\
\hline WWR 1-E & $\begin{array}{c}\text { Eastern Walls_95\% -- Window Shades - East_2/3 Win Height -- Window Glass Types - } \\
\text { East_Trp LoE }\end{array}$ \\
\hline WWR 2-E & $\begin{array}{c}\text { Eastern Walls_65\% -- Window Shades - East_2/3 Win Height -- Window Glass Types - } \\
\text { East_Trp LoE }\end{array}$ \\
\hline WWR 3-E & $\begin{array}{c}\text { Eastern Walls_30\% -- Window Shades - East_2/3 Win Height -- Window Glass Types - } \\
\text { East_Trp LoE }\end{array}$ \\
\hline
\end{tabular}

\subsection{Energy Simulations}

This insulation of building properties can reduce the energy consumption and water use reduction from daily life (Amann et al., 2012). The parameters have been incorporated in this study to increase the LEED certification and reduce the lifecycle cost.

Figure 6 represents the total simulation process for various combinations. Objectives of these simulations are to find out the effect of various combinations on energy consumption. A combination of different insulations has been run. After one simulation is done with the base requirements, the LEED $(B D+C)$ credits are calculated according to USGBC guideline. According to this certification, the model is being certified. Then the passive technologies are alternated and repeated the whole simulation process. In addition, impact of passive technologies on the level of LEED rating and costing is analyzed. 


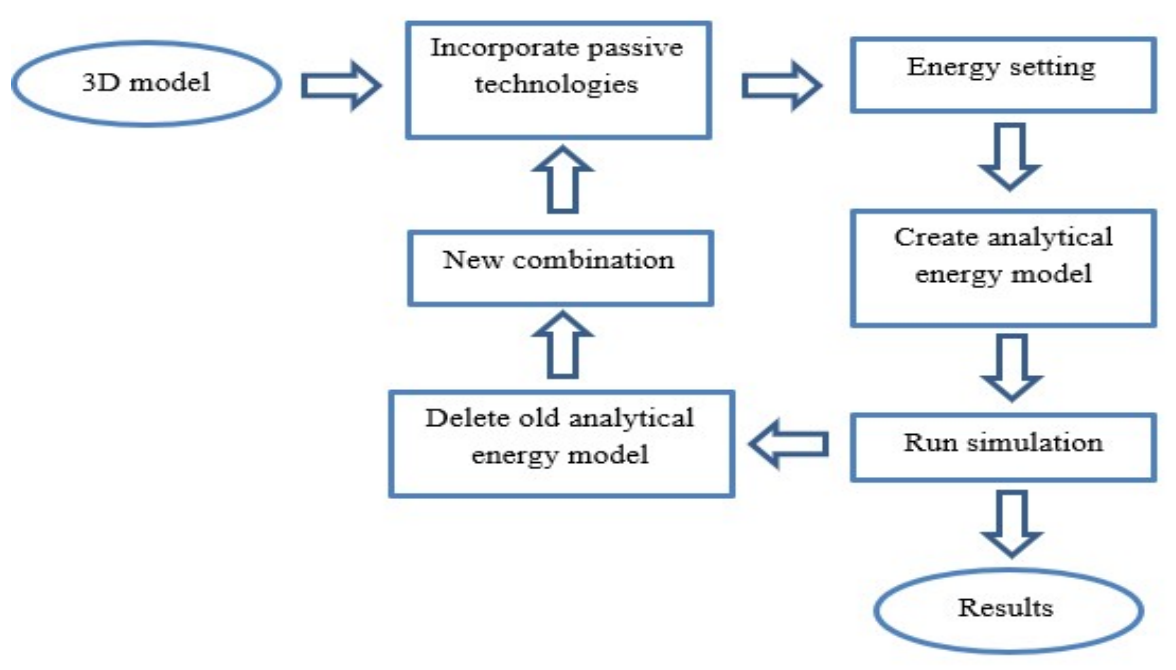

Figure 6: Overall Process of Energy Simulation.

\subsection{Assessment of Payback Period}

Equation 1 is used for calculating the payback period (Thornton et al., 2011),

Payback period $=\frac{\text { Increased investment }}{\text { Reduction of annual energy cost }}$

\section{RESULTS AND DISCUSSION}

In this study, the categories are changed to achieve credit, energy consumption, initial investment and lifecycle cost. Comparison is done among the cases by the points they get by certifying, which mostly depends on those three varying categories. Moreover, the case with lower annual energy consumption, greatest water efficiency and best indoor air quality will get the greatest LEED certification and that combination will be the best. All the simulation results of case-1 to case-4 are done considering ASHRAE 90.1.2010 and USGBC guideline. Moreover, the cost estimations and the payback period are calculated.

\subsection{Earned LEED Points}

From case- 1 to case- 4 the variable properties are passive technologies. Table 7 shows the achieved LEED (BD $+C)$ points on various categories for case 1 to case 4 .

Table 7: Breakdown of the Achieved Credit Points for Each Case of Simulation

\begin{tabular}{cccccc}
\hline Category & Total Points & Case-1 & Case-2 & Case-3 & Case-4 \\
\hline Integrative Process (IP) & 1 & 1 & 1 & 1 & 1 \\
Location \& Transportation (LT) & 16 & 11 & 11 & 11 & 11 \\
Sustainable Sites (SS) & 10 & 9 & 9 & 9 & 9 \\
Water Efficiency (WE) & 11 & 2 & 3 & 4 & 5 \\
Energy Atmosphere (EA) & 33 & 3 & 12 & 14 & 17 \\
Material Resources (MR) & 13 & 8 & 8 & 8 & 8 \\
Indoor Environmental Quality (IEQ) & 16 & 8 & 8 & 8 & 8 \\
Innovation (I) & 6 & 1 & 1 & 1 & 1 \\
Regional Priority (RP) & 4 & 0 & 0 & 0 & 0 \\
\hline
\end{tabular}

The passive technologies incorporated to the residential building of the different cases include wall insulation, roof insulation, window wall ratio (WWR), building orientation, HVAC system, window type and water fixture (Zach et al., 2013; Mccann, 1931). This also shows the fluctuation of the credentials due to change of passive 
technologies which can be determined in the early project initiation phase. Figure 7 shows the earned LEED $(\mathrm{BD}+\mathrm{C})$ points for the alternative design such as case 1 to case 4 . It has been found that earned points for case 1 , case 2 , case 3 and case 4 is $43,52,56 \& 60$ respectively.

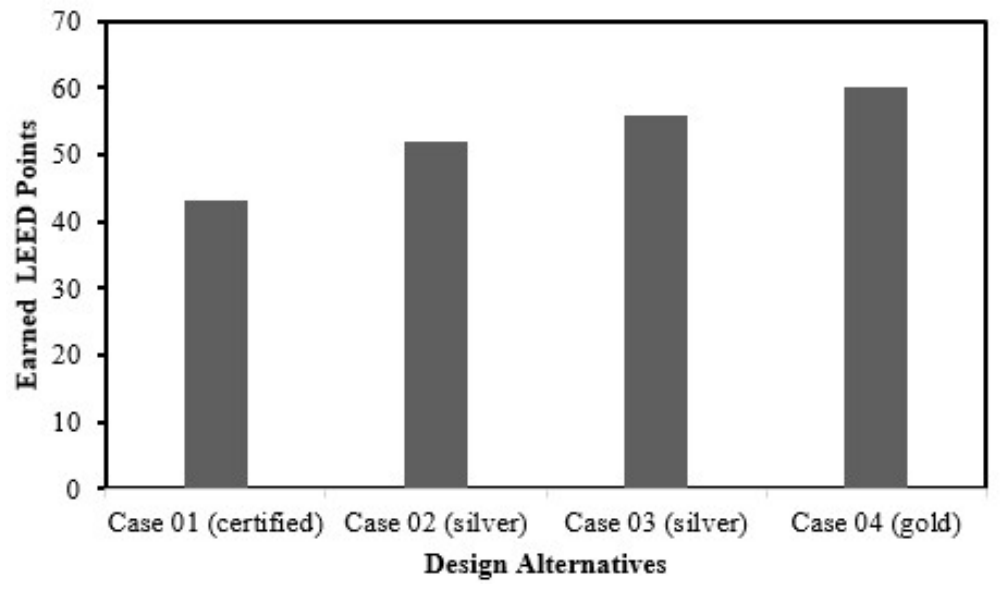

Figure 7: Earned points on various alternatives.

\subsection{Initial investment for a LEED $(B D+C)$ certification}

Since features like water efficiency and energy \& atmosphere have been incorporated to enhance the building performance, changing different passive technologies (Wall Insulation, Roof Insulation, Window Wall Ratio, building orientation, Window Properties and Water Fixture) and installing PV panel, the initial investment has gradually increased from case 1 to case 4 together with level of certification as well (Figure 8).

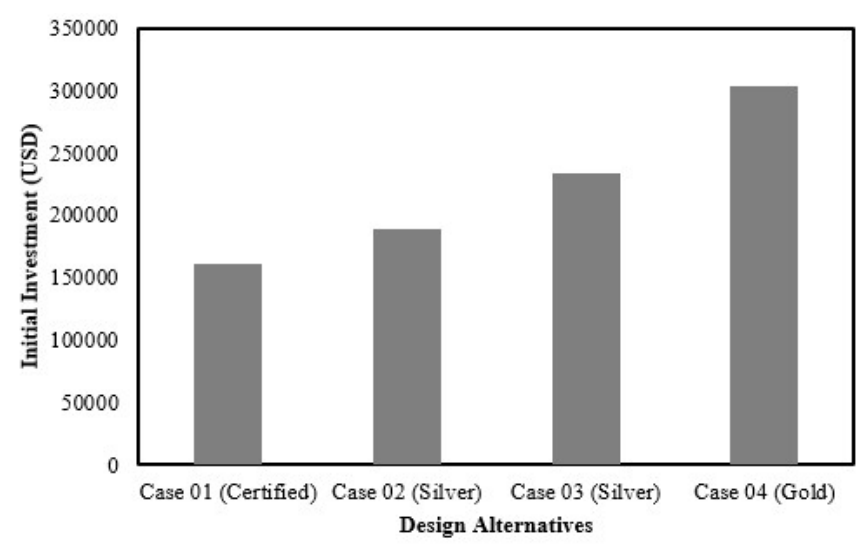

Figure 8: Initial Cost for high performance green building

The initial investment is found to increase by $16.65 \%$ from case 1 to case 2 while the level of certification improves from certified to Silver. Similarly, the initial investment is found to spike by $24.33 \%$ from case 1 to case 4 while level of certification enhances from certified to gold. Therefore, it is quite evident that the certification raises with the increase of initial investment.

\subsection{Life Cycle Energy Consumption}

Figure 9 shows that by incorporating passive technologies, PV panel the energy consumption rate got decreased. Form Case- 1 to case- 2 , it decreases about $12 \%$, Case- 1 to case- 3 about $14 \%$ and in the end, it reduced by $18 \%$ and the model got certified by gold. In this whole process energy consumption reduced from 75,000 $\mathrm{MW}$ to 50,000 MW. Lifecycle cost is depended on the annual energy consumption rate and it is a straight and easy measure to interpret economic evaluation. 


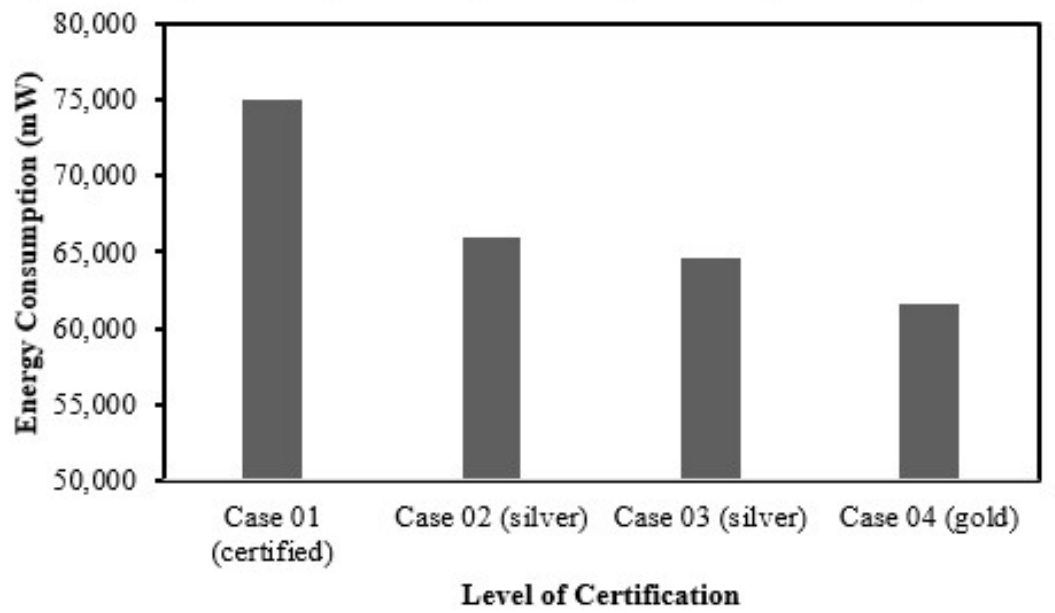

Figure 9: Whole Life Cycle Energy Consumption at Various Simulation.

\subsection{Life Cycle Cost}

The impact of life cycle cost to achieve various LEED $(\mathrm{BD}+\mathrm{C})$ certification is shown in figure 10 . Here, the certification was increased with the increment of initial investment by $63.89 \%$ while lifecycle cost reduced by $24 \%$. The amount of additional initial investment was invested to increase building performance which was later offset from saving during operation and maintenance.

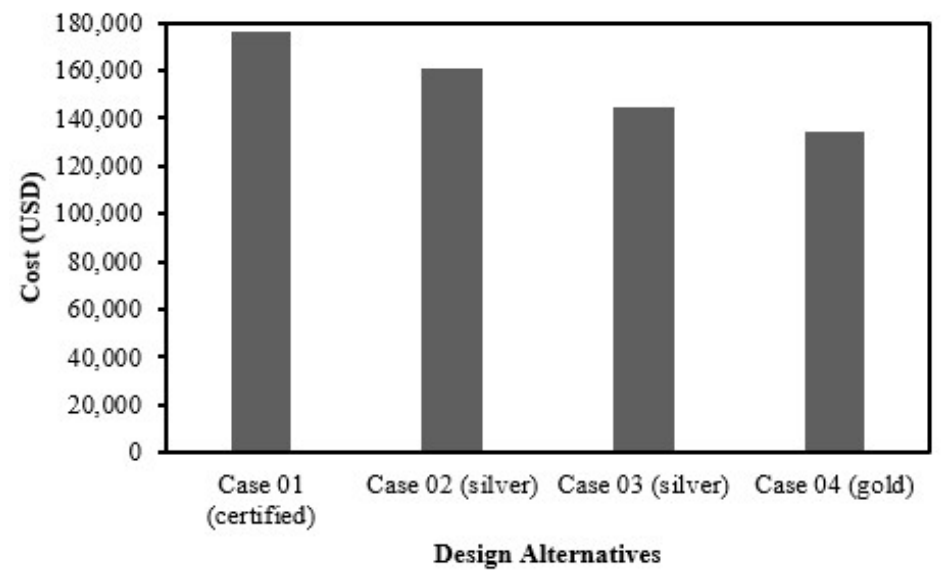

Figure 10: Variation of Lifecycle Cost for Various Design Alternatives.

\subsection{Generated Renewable Energy from PV Panels}

PV and wind turbine are not able to produce enough energy to fulfil the energy demand of the building. Solar Photovoltaic (PV) energy directly converts the sun's light into energy by solar PV panels. In this research PV panels are used at the upper rooftop level of this residential building. Figure 11 shows the installation of the PV panel on roof of the building. 


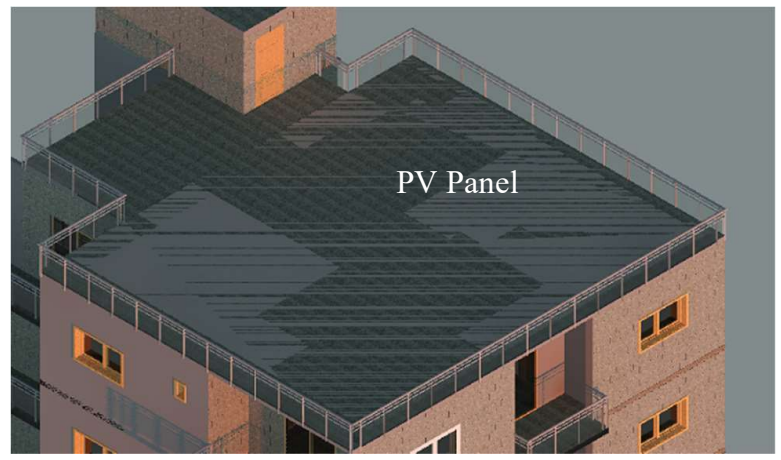

Figure 11: Provision of PV Panel at Upper Roof.

Moreover, the electricity output from the PV Panel can be estimated by the formula (2).

$E=A * r * H * P R$

Where, $\mathrm{E}=$ Renewable Energy $(\mathrm{kWh})$

$\mathrm{A}=$ Total solar panel Area $\left(\mathrm{m}^{2}\right)$

$r=$ solar panel yield or efficiency $(\%)($ Assume $15 \%)$

$\mathrm{H}=$ Annual average solar radiation on tilted panels (shadings not included) and $45^{\circ}$ is considered here.

$\mathrm{PR}=$ Performance ratio, coefficient for losses (range between 0.5 and 0.9 , default value $=0.75$ )

In this study, the area of PV panel $=775 \mathrm{sft}$.

Thus, total renewable energy annually, $\mathrm{E}=13505 \mathrm{kWh}$

Therefore, the building can produce a certain amount of the energy requirement of the residential building.

The installation cost of the PV panel will be recovered from its annual electricity production.

\subsection{Assessment of Payback Period}

The total lifecycle period is assumed as 30 years. The payback period depends on the increased investment, which was done for incorporating other passive technologies.

$$
\begin{gathered}
\text { Payback period }=\frac{\text { Increased investment }}{\text { Reduction of annual energy cost }} \\
\begin{array}{r}
\text { Payback period }=\frac{24306820-12919227}{1022240} \\
=11 \text { Years }
\end{array}
\end{gathered}
$$

Hence, by using equation (1) it was found that an increase of certification by investing some capital, can be paid back by the time of 11 years. However, it has to be noted that government's energy incentives, tax breaks, loan solutions or system de-rating factors are not considered in this payback calculation.

\section{CONCLUSIONS}

The concept of green building is related to enhance building performance, which is depended on water efficiency, energy consumption, indoor environmental quality and renewable energy supply, building orientation, building shape. The buildings are made sustainable by incorporating BIM technology and assessed the level of green building in accordance with LEED $(\mathrm{BD}+\mathrm{C})$ guideline. From the simulated results it was found that the level of certification for the base case (case 1) is certified and the last case (case -4) is ended up with Gold and the best configuration for case 4 is summarized below:

- $\quad$ HVAC $=$ Residential 14 SEER/0.9 AFUE Split/Packaged Gas $<5.5$ ton

- Wall Pattern= Wall 3 (4" brick wall +4 " plywood +2 " cork and 2.5 " brick wall +2 " plywood +0.5 " cork)

- Roof Pattern= Roof 3 (4" lightweight concrete+ 2" rock wool)

- Building Orientation $=90^{\circ}$ rotation

- Window Wall Ratio=WWR 2-N ( Northern Walls_65\% -- Window Shades - North_2/3 Win Height -Window Glass Types - North Trp L ) 
In addition, from this study it has found that though the initial investment cost was high and grew by $63.89 \%$ but Installation cost of the passive technologies can be payback within 11 years.

\section{ACKNOWLEDGEMENT}

The authors would like to express their heartfelt thanks to the national and international green building expert who had provided their valuable advice to conduct this research.

\section{REFERENCES}

Amann, J., Wilson, A. \& Ackerly, K. 2012. Consumer Guide to Home Energy Savings: Save Money, Save the Earth, New Society Publishers.

Azhar, S. 2010. BIM for sustainable design: results of an industry survey. Journal of Building Information Modeling, 4, 27-28.

Azhar, S., Carlton, W. A., Olsen, D. \& Ahmad, I. 2011. Building information modeling for sustainable design and LEED ${ }^{\circledR}$ rating analysis. Automation in construction, 20, 217-224.

Benmansour, N., Agoudjil, B., Gherabli, A., Kareche, A. \& Boudenne, A. 2014. Thermal and mechanical performance of natural mortar reinforced with date palm fibers for use as insulating materials in building. Energy and Buildings, 81, 98-104.

Bolman, L. G. \& Deal, T. E. 2011. The wizard and the warrior: Leading with passion and power, John Wiley \& Sons.

Boukhattem, L., Boumhaout, M., Hamdi, H., Benhamou, B. \& Nouh, F. A. 2017. Moisture content influence on the thermal conductivity of insulating building materials made from date palm fibers mesh. Construction and Building Materials, 148, 811-823.

Cidell, J. 2009. A political ecology of the built environment: LEED certification for green buildings. Local Environment, 14, 621-633.

Council, U. G. B. 1996. Sustainable building technical manual: green building design, construction, and operations.

Council, U. G. B. 1998. US green building council, US Green Building Council.

Jalaei, F. \& Jrade, A. 2015. Integrating building information modeling (BIM) and LEED system at the conceptual design stage of sustainable buildings. Sustainable Cities and Society, 18, 95-107.

Mccann, J. H. 1931. Protective cover for plumbing fixtures. Google Patents.

Ragheb, A., El-Shimy, H. \& Ragheb, G. 2016. Green architecture: A concept of sustainability. Procedia-Social and Behavioral Sciences, 216, 778-787.

Schmalensee, R., Stoker, T. M. \& Judson, R. A. 1998. World carbon dioxide emissions: 1950-2050. Review of Economics and Statistics, 80, 15-27.

Thornton, B. A., Rosenberg, M. I., Richman, E. E., Wang, W., Xie, Y., Zhang, J., Cho, H., Mendon, V. V., Athalye, R. A. \& Liu, B. 2011. Achieving the 30\% goal: Energy and cost savings analysis of ASHRAE Standard 90.1-2010. Pacific Northwest National Lab.(PNNL), Richland, WA (United States).

Wu, W. \& Issa, R. Feasibility of integrating building information modeling and LEED certification process. Proc., Int. Conf. on Computing in Civil and Building Engineering, W. Tizani, ed., Univ. of Nottingham, Nottingham, UK, 2010.

Zach, J., Hroudová, J., Brožovský, J., Krejza, Z. \& Gailius, A. 2013. Development of thermal insulating materials on natural base for thermal insulation systems. Procedia Engineering, 57, 1288-1294.

(C) 2021 the Authors. Journal of Engineering Science published by Faculty of Civil Engineering, Khulna University of Engineering \& Technology. This is an open access article under the terms of the Creative Commons AttributionNonCommercial-NoDerivatives License, which permits use and distribution in any medium, provided the original work is properly cited, the use is non-commercial and no Modifications or adaptations are made. 